\title{
The Effect of Problem Based Learning Models in Online Learning Settings on Student Cognitive Learning Outcomes in History Subjects
}

\section{Megiridha Loppies $^{1 *}$, Aip Badrujaman², Sarkadi ${ }^{3}$}

1,2,3Postgraduate Historical Education Study Program, State University of Jakarta, East Jakarta, Indonesia

A R T I C L E I N F O

Article history:

Received 18 December 2020

Received in revised

Form 06 January 2021

Accepted 1 February

2021

Available online 09

February 2021

Keywords:

Problem Based Learning,

Online Learning,

Cognitive Learning

\section{A B S T R A C T}

This study aims to examine the effect of problem-based learning models on the achievement of student learning outcomes in History subjects. This research was conducted at Pusaka 1 Jakarta Senior High School. The method used in this research is quantitative quasi-experimental with a nonequivalent control group design model. The population in this study were all students of class XI IPS as many as four classes at SMAS Pusaka 1 Jakarta. The research sample was determined by purposive sampling technique to determine one class as an experimental class using a problem-based learning model and another class as a control class using conventional learning models. The results of hypothesis testing using the t test, obtained tcount $=9.25,>$ from ttable $=1.99$. Thus, $\mathrm{Ho}$ is rejected and $\mathrm{Ha}$ is accepted, so it can be concluded that there is a significant influence between problem-based learning models in online learning settings on cognitive learning outcomes of class XI IPS at SMAS Pusaka 1 Jakarta on History Subjects.

\section{Introduction}

Education is an important part of the socio-cultural life of a nation's people. Education plays an important role in the development of a nation (Mustari \& Rahman, 2014; Wijaya et al., 2016), because education will produce a generation of intelligent people (Ramdani et al., 2019), have character (Wijaya, 2018), knowledgeable and have good quality to build the nation (Ghazali, 2019). Thus, quality human resources are the result of the educational process. In the current era of digitalization, the functions and goals of education that are carried out through learning activities must be able to provide the widest possible opportunity for students to develop themselves (Supriatna, 2018). In this case, the teacher is the main subject in charge of carrying out the functions and goals of education (Subekti et al., 2017). Teachers are a resource that plays a role in planning, implementing, and evaluating education (Astuti, 2017), especially education that is implemented in schools, so that the learning process that is expected to occur is a process that can develop the potential of students in a comprehensive and integrated manner. Therefore, teachers are not only required to deliver subject matter, but more than that, teachers must have pedagogical abilities in order to be able to actualize their strategic role in shaping student character through personality development and prevailing values (Ahyanuardi et al., 2018).

In the situation and condition of Indonesia and even the world today which is being hit by the global covid-19 pandemic, a major change has occurred in various aspects of human life. All human activities are restricted and diverted from the home. Such situations and conditions also affect the educational aspect. The role of the educational aspect is in a quite crucial position (Wahyono et al., 2020) and is a dilemma. To break the chain of spreading covid19 - which is feared by students and even teachers can act as carriers and spreaders of disease without symptoms - almost all countries have eliminated teaching and learning activities in schools (Wahyono et al., 2020). In fact, on March 24, 2020, the Minister of Education and Culture of the Republic of Indonesia issued Circular Letter Number 4 of 2020 concerning Implementation of.

Education Policy in an Emergency for the Spread of Covid-19, in this Circular it was explained that the learning process is carried out at home through online / distance learning (Wahyu , 2020). From then on, all learning activities were shifted into online, offline and distance education forms, in accordance with the conditions experienced by schools in each district and city. Until the results of this study are 
summarized, learning in schools where researchers conduct research is still using online learning. Online learning is an educational innovation that involves elements of information technology in learning (Fitriyani et al., 2020). Some applications that can be used to facilitate teachers and students in online learning are Google Clasroom (GC), Google Meet, Google Form, Zoom Cloud Meetings and Whatsapp (WA). Online learning makes it easy for teachers and students to interact anywhere and anytime. However, online learning also has its drawbacks, namely that teachers cannot interact directly with students.

In learning, history as a subject that studies human past events in the concept of space and time requires teacher creativity and innovation in designing and developing attractive learning models in order to invalidate the assumption of 'history as a boring subject'. especially during the Covid 19 pandemic where learning was taking place using an online system. The teacher must become a role model in carrying out learning with an online system that utilizes various technological applications that can support the success of the teaching and learning process to achieve the goals of learning history. History learning is expected to be able to lead students to achieve maximum learning outcomes or at least achieve the minimum completeness criteria (KKM). Learning outcomes are the result of achieving predetermined learning goals. (Fiqri et al., 2018) argue that learning outcomes can be in the form of attaining a form of behavior change that tends to persist from the cognitive, affective, and psychomotor domains of the learning process carried out within a certain time. The cognitive domain aims to train students' intellectual abilities, the affective realm aims to train attitudes, emotions, appreciation and appreciation of values, norms and something being studied, while the psychomotor domain is related to the ability to carry out physical activities in various subjects. Thus, what is meant by the results of learning history is the result of the achievement of the cognitive, affective and psychomotor domains of history subjects.

In the revised 2013 curriculum, student learning outcomes in history subjects must meet the specified minimum completeness criteria (KKM), namely 75. However, the current reality is that there are still many problems in learning history. One of them is the value of student learning outcomes which is still low. Based on an interview with a history teacher at a private high school in Jakarta, there are still many students whose scores are still below the KKM when given midterm examinations. The low score of students that shows their learning outcomes encourages the author to conduct research to improve student learning outcomes. Thus, according to the author, an innovative historical learning model is needed, which can improve student learning outcomes in history subjects.

One of the innovative learning models that are predicted to improve student learning outcomes is the problem-based learning model. Problem-based learning is a learning method that refers to the student-centered constructivism paradigm (Erawanto \& Santoso, 2016; Ulger, 2018). In line with that, Arends (Wulansari et al., 2019), states that problem-based learning is a learning model that is based on constructivism and accommodates student involvement in learning and is involved in contextual problem solving. In problem-based learning, authentic problems become the starting point in learning. Problembased learning provides opportunities for students to learn how to learn (Hallinger \& Bridges, 2017). Various studies have proven that problem-based learning is able to improve student learning outcomes, including research (Ulger, 2018) which reveals that problem-based learning models can help students solve problems and help improve thinking creativity. The research results of Yulianti et al., (2019) state that the implementation of a problem-based learning model based on STEM (Science, Technology, Engineering and Mathematic) can improve knowledge achievement (cognitive), skills (psychomotor) and can develop disciplinary character, curiosity, communicative and cooperation. The results of Choi et al., (2014) revealed that student learning outcomes in problem-based learning groups increased across all measured abilities, while student scores in traditional lecture groups decreased in problem-solving and independent learning. Furthermore, Qomariyah (2019) showed the results of his research that the problem-based learning model can improve student learning outcomes at MAN 1 Pati.

Based on the background description above, the authors are interested in conducting a study with the title: the influence of problem-based learning models in online learning settings on student cognitive learning outcomes in history subjects at Pusaka 1 Jakarta Senior High School.

\section{Methods}

This type of research is included in the quantitative research type of quasi experiment. This research was conducted in early September to mid October 2020 at SMAS Pusaka 1 Jakarta. The research design used was the nonequivalent control group design. The population in this study were all students of class XI IPS as many as four classes totaling 140 students at SMAS Pusaka 1 Jakarta. The research sample was determined by purposive sampling technique. Purposive sampling is a sampling technique by selecting a sample among the population according to what the researcher wants, so that the sample can represent the characteristics of the population that have been known previously (Pinandita, I. Purwanti, 
E., \& Utoyo, 2012). Purposive sampling is used to determine one class as an experimental class using a problem-based learning model and another class as a control class using a conventional learning model. Thus, the research sample consisted of two classes, namely class XI IPS 2 as the experimental class and class XI IPS 3 as the control class.

In this study, researchers collected data using a learning outcome test instrument which aims to measure the achievement of student learning outcomes in history subjects. The test instrument consists of 40 multiple choice (PG) questions that have been tested and meet the criteria for validity and reliability. The learning outcome test was carried out twice, namely at the beginning of learning (pre-test) and at the end of learning (posttest). For the research class (experimental class and control class), the pre-test was conducted to determine the level of students' initial ability to the teaching material at the beginning of the lesson. After that, a post-test was carried out at the end of the lesson to determine the level of student ability after being given the material with treatment (problem-based learning models and conventional models). In simple terms, the research design can be described in Table 1.

Table 1. The experimental design nonequivalent control group design

\begin{tabular}{llll}
\hline Class & Pre-Test & Treatment & Post-Test \\
\hline Experiment & $\mathrm{Q}_{1}$ & PBM $(\mathrm{X} 1)$ & $\mathrm{Q}_{2}$ \\
Control & $\mathrm{Q}_{3}$ & Conventional $(\mathrm{X} 2)$ & $\mathrm{Q}_{4}$ \\
\hline
\end{tabular}

The data analysis technique used in this research is parametric statistics which consist of homogeneity test, normality test and hypothesis test. Thus, the data analysis of the pre-test results was carried out by the homogeneity test using the variance test ( $\mathrm{F}$ test). While in the post test, the data analysis for normality test used the Chi Square test, the homogeneity test used the variance test (F test) and the hypothesis test used the $t$ test to determine the effect of problem-based learning models on student cognitive learning outcomes.

\section{Result and Discussion Results}

In this study, learning activities were carried out 4 times with the subject matter of the major world revolutions and their effects on today's life. Learning activities are carried out online considering the situation and condition of Indonesia and even the world is currently being hit by the global Covid-19 pandemic. Thus, researchers use the zoom room application and Google Classroom (GC) to apply learning activities. The Google Classroom application is used for classes that use problem-based learning models and zoom space applications for classes that implement conventional learning models.

Before the subject matter is given to students, a pre-test is carried out to determine the students' initial abilities towards the subject matter. The results of the pre-test of the experimental class and the control class on the material of the major world revolutions and their effects on contemporary life can be seen in Table 2.

Table 2. The pretest results of the experimental class and control class

\begin{tabular}{|c|c|c|c|c|c|}
\hline No & Data source & $\begin{array}{l}\text { The highest } \\
\text { score }\end{array}$ & Lowest Value & $\begin{array}{l}\text { Average } \\
\text { value }\end{array}$ & $\begin{array}{l}\text { Standard } \\
\text { Deviation }\end{array}$ \\
\hline 1 & Experiment Class & 60 & 20 & 42,63 & 10,36 \\
\hline 2 & Control Class & 60 & 18 & 43,26 & 10,94 \\
\hline
\end{tabular}

Based on the pre-test results in Table 2, the highest score is the same in the experimental class and the control class, namely 60 , the lowest score for the experimental class is 20 and the control class is 16, while the average value for the experimental class is 42,63 and the control class is 43,26 . - The average of these two class groups is still in the low category because it is still below the Minimum Completion Criteria (KKM). This means that both classes have approximately the same initial ability.

After the pre-test was carried out, the homogeneity test was then carried out for the pre-test data with the aim of knowing the data variants of the two sample classes before being given treatment. The homogeneity test uses the variance test ( $\mathrm{F}$ test) to obtain the assumption that the initial conditions of the two classes before being treated are the same. Table 3 showing the results of the pre-test homogeneity in the experimental class and the control class. 
Table 3. Homogeneity Test Results of the Pre-Test Score of the Experiment Class and the Control Class

\begin{tabular}{lllllll}
\hline No & Data source & Variance & F Count & $\begin{array}{l}\text { F Table with } \\
\text { Significance Level }\end{array}$ & Information \\
\hline 1 & Experiment Class & 19,91 & 1,51 & 1,79 & & Homogeneous \\
2 & Control Class & 15,93 & & & \\
\hline
\end{tabular}

After the homogeneity test was carried out using the variance test ( $F$ test) it was proven that Fcount $1.51<1.79$ Ftable at a significant level of 5\%. Then both classes are homogeneous. In other words, students' prior knowledge in the two classes used as research samples before being given treatment was more or less the same. Thus, the two classes sampled can represent the population in the study.

After the pre-test is done, it is continued with the provision of treatment, namely problem-based learning for the experimental class and conventional learning for the control class whose post-test results are described in Table 4.

Table 4. Post-Test Results for Experiment Class and Control Class

\begin{tabular}{llcccc}
\hline No & Data source & The highest score & Lowest Value & Average value & $\begin{array}{c}\text { Standard } \\
\text { Deviation }\end{array}$ \\
\hline 1. & Experiment Class & 95 & 64 & 73,42 & 9,77 \\
2. & Control Class & 74 & 54 & 66,29 & 9,05 \\
\hline
\end{tabular}

Based on the post test results in the experimental class and the control class, it is known that both classes experienced an increase in their learning outcomes. However, it is clear that the experimental class scored higher (maximum score), namely 95. Meanwhile, the maximum score in the control class was 74. The minimum score for the experimental class was 64 , while the minimum score for the control class was 54. So the average score for the experimental class was 73,42 and the mean value of the control class was 66.29. In other words, learning using a problem-based learning model has a higher value than learning using a conventional model.

The post test results after being given this treatment are then tested again for homogeneity and normality. Similar to the pre-test, the homogeneity test aims to determine the variant of the data after being given treatment. Table 5 showing the homogeneity test results of the post test results in the experimental class and the control class.

Table 5. Homogeneity test of the results of the post test of the experimental class and the control class

\begin{tabular}{llllll}
\hline No & Data source & Variance & F Count & $\begin{array}{l}\text { F Table with } \\
\mathbf{5 \%} \text { Sig Level }\end{array}$ & Information \\
\hline 1. & Experiment Class & 20,95 & 2,01 & 2,62 & Homogeneous \\
2. & Control Class & 18,72 & & & \\
\hline
\end{tabular}

Homogeneity test data using the variance test (F test) shows that Fcount $2.01<2.62$ Ftable at a significant level of 5\%. Thus, the data on student learning outcomes after being treated are homogeneous. In other words, students' knowledge after being given problem-based and conventional learning is more or less the same.

Furthermore, the data from the post-test results were tested again for normality using the Chi Square test to find out whether the post-test result data had a normal distribution or not. In addition, the data normality test is intended to determine what statistical prerequisites will be used in hypothesis testing. Table 6 showing the results of the post-test data normality test for the experimental class and the control class.

Table 6. The normality test of the results of the post test of the experimental class and the control class

\begin{tabular}{|c|c|c|c|c|c|}
\hline No & Data source & X2 Count & Table & $\mathbf{a}$ & Information \\
\hline & & & \multicolumn{3}{|l|}{ Significant Level of $5 \%$} \\
\hline 1. & Experiment Class & 5,88 & 11,93 & & Normal \\
\hline 2. & Control Class & 4,63 & 9,02 & & Normal \\
\hline
\end{tabular}

Table 6 shows the results of the post-test that have been calculated for normality using the chi square test formula, so it is known that the post-test result data is normally distributed. This shows that the hypothesis testing in this study uses parametric statistics. By considering the results of the calculation 
of the homogeneity test, it is known that the two classes are homogeneous, so that the parametric statistics used is the $t$ test. The $t$ test analysis was conducted to determine the effect of problem-based learning models in online learning settings on student cognitive learning outcomes. After testing the hypothesis using the $t$ test, it is obtained that $t$ count $=9.25$, greater than $t$ table $=1.99$. Thus, Ho was rejected and Ha was accepted. This means that there is an influence between problem-based learning models in online learning settings on cognitive learning outcomes of class XI IPS at Pusaka 1 Jakarta in History subjects.

\section{Discussion}

Problem-based learning in online learning settings can be said to have gone well. The experimental class treated with the problem-based learning model tended to be more active than the control class given the conventional learning model. In the experimental class, students can learn actively, ask questions, express opinions via the chat column, even do a given assignment very well, based on steps to gather information, think critically to solve problems and be able to link information in order to show and explain causal relationship of an actual event. This is in accordance with the theory that in problembased learning, students are given the opportunity to learn actively, seek information, think critically and solve the problems they face so that they are more sensitive, more independent and actively develop their own skills and are even able to face all the challenges of the times.

Based on the results of research and data analysis, it can be concluded that: the results of hypothesis testing using the $t$ test, obtained $t$ count $=9.25$, greater than $t$ table $=1.99$. Thus, Ho was rejected and Ha was accepted. This means that there is an influence between problem-based learning models in online learning settings on cognitive learning outcomes of class XI IPS at Pusaka 1 Jakarta in History subjects. Problem-based learning models in online learning settings have an effect on improving student cognitive learning outcomes so that they can be used as an alternative learning model that can activate students, practice critical thinking skills and problem-solving abilities, and independent learning.

The suggestions that can be given based on the research results are: 1). In learning that uses a problem-based learning model, teachers should need to design and prepare contextual problems that will be given to students to solve, 2). Teachers need to master various learning sources so that when the teacher provides conclusions, all information obtained by students from various sources can be represented, 3). Teachers should need to improve their personal skills with a variety of innovative learning media, especially those related to online learning.

Problem-based learning is a learning method that refers to the student-centered constructivism paradigm (Erawanto \& Santoso, 2016; Ulger, 2018). In line with that, Arends (Wulansari et al., 2019), states that problem-based learning is a learning model that is based on constructivism and accommodates student involvement in learning and is involved in contextual problem solving. In problem-based learning, authentic problems become the starting point in learning. Problem-based learning provides opportunities for students to learn how to learn (Hallinger \& Bridges, 2017).

Various studies have proven that problem-based learning is able to improve student learning outcomes, including research (Ulger, 2018) which reveals that problem-based learning models can help students solve problems and help improve thinking creativity. The research results of Yulianti et al., (2019) state that the implementation of a problem-based learning model based on STEM (Science, Technology, Engineering and Mathematic) can improve knowledge achievement (cognitive), skills (psychomotor) and can develop disciplinary character, curiosity, communicative and cooperation. The results of Choi et al., (2014) revealed that student learning outcomes in problem-based learning groups increased across all measured abilities, while student scores in traditional lecture groups decreased in problem-solving and independent learning. Furthermore, Qomariyah (2019) showed the results of his research that the problem-based learning model can improve student learning outcomes at MAN 1 Pati.

\section{Conclusion}

Based on the research findings and discussion, can be concluded that there is an influence between problem-based learning models in online learning settings on cognitive learning outcomes of class XI IPS at Pusaka 1 Jakarta in History subjects. The suggestions that can be given based on the research results are: 1 ). In learning that uses a problem-based learning model, teachers should need to design and prepare contextual problems that will be given to students to solve, 2). Teachers need to master various learning sources so that when the teacher provides conclusions, all information obtained by students from various sources can be represented, 3). Teachers should need to improve their personal skills with a variety of innovative learning media, especially those related to online learning. 


\section{References}

Ahyanuardi, A., Hambali, H., \& Krismadinata, K. (2018). Pengaruh Kompetensi Pedagogik Dan Profesional Guru Sekolah Menengah Kejuruan Pasca Sertfikasi Terhadap Komitmen Guru Melaksanakan Proses Pembelajaran. INVOTEK: Jurnal Inovasi Vokasional Dan Teknologi, 18(1), 67-74. https://doi.org/10.24036/invotek.v18i1.169.

Astuti, S. (2017). Supervisi Akademik Untuk Menigkatkan Kompetensi Guru Di SD Lboratorium Uksw. Scholaria, 7(1), 49-59. https://doi.org/10.24246/j.scholaria.2017.v7.i1.p49-59.

Choi, E., Lindquist, R., \& Song, Y. (2014). Effects of problem-based learning vs. traditional lecture on Korean nursing students' critical thinking, problem-solving, and self-directed learning. Nurse Education Today, 34(1), 52-56. https://doi.org/10.1016/j.nedt.2013.02.012.

Erawanto, U., \& Santoso, E. (2016). Pengembangan Modul Pembelajaran Berbasis Masalah Untuk Membantu Meningkatkan Berfikir Kreatif Mahasiswa. JINoP (Jurnal Inovasi Pembelajaran), 2(2), 427. https://doi.org/10.22219/jinop.v2i2.2629.

Fiqri, Y. Al, Kurniawati, K., \& Sarkadi, S. (2018). Pengaruh Metode Pembelajaran dan Minat Baca Terhadap Hasil Belajar Sejarah Siswa SMAN 01 Argamakmur Bengkulu Utara. JTP - Jurnal Teknologi Pendidikan, 20(1), 73-86. https://doi.org/10.21009/ITP2001.6.

Fitriyani, Y., Fauzi, I., \& Sari, M. Z. (2020). Motivasi Belajar Mahasiswa Pada Pembelajaran Daring Selama Pandemik Covid-19. Profesi Pendidikan Dasar, 7(1), 121-132. https://doi.org/10.23917/ppd.v7i1.10973.

Ghazali, A. (2019). Urgensi pendidikan karakter yang sesuai dengan falsafah bangsa indonesia. Kajian Pendidikan Islam Dan Studi Islam, 2(1), 16-31.

Hallinger, P., \& Bridges, E. M. (2017). A Systematic Review of Research on the Use of Problem-Based Learning in the Preparation and Development of School Leaders. Educational Administration Quarterly, 53(2), 255-288. https://doi.org/10.1177/0013161X16659347.

Mustari, M., \& Rahman, M. T. (2014). Manajemen Pendidikan (R. G. Persada (ed.); pp. 226-258).

Pinandita, I. Purwanti, E., \& Utoyo, B. (2012). Pengaruh teknik Relaksasi Genggam Jari Terhadap Penurunan Intensitas Nyeri Pada Pasien Post Operasi Laparatomi. Jurnah Kesehatan Perawatan, 8(1), 32-43. http://ejournal.stikesmuhgombong.ac.id/JIKK/article/view/66.

Qomariyah, S. N. (2019). Effect of Problem Based Learning Learning Model to Improve Student Learning Outcomes. International Journal of Educational Research Review, 2009, 217-222. https://doi.org/10.24331/ijere.518056.

Ramdani, Z., Amrullah, S., \& Felisima Tae, L. (2019). Pentingnya Kolaborasi dalam Menciptakan Sistem Pendidikan yang $\quad$ Berkualitas. $\quad$ MediaPSI, $\quad$ 5(1), https://doi.org/10.21776/ub.mps.2019.005.01.4.

Subekt, H., Taufiq, M., Susilo, H., Ibrohim, I., \& Suwono, H. (2017). Mengembangkan Literasi Informasi Melalui Belajar Berbasis Kehidupan Terintegrasi Stem Untuk Menyiapkan Calon Guru Sains Dalam Menghadapi Era Revolusi Industri 4.0: Revieu Literatur. Education and Human Development Journal, 3(1), 81-90. https://doi.org/10.33086/ehdj.v3i1.90.

Supriatna, A. (2018). Kegiatan Lesson Study sebagai Upaya Guru untuk Menemukan Pembelajaran yang Memenuhi Keperluan Anak Hidup pada Zamannya (Era Revolusi Industri 4.0). Edusainstek, 1(1), 1-5.

Ulger, K. (2018). The effect of problem-based learning on the creative thinking and critical thinking disposition of students in visual arts education. Interdisciplinary Journal of Problem-Based Learning, 12(1). https://doi.org/10.7771/1541-5015.1649.

Wahyono, P., Husamah, H., \& Budi, A. S. (2020). Guru profesional di masa pandemi COVID-19: Review implementasi, tantangan, dan solusi pembelajaran daring. Jurnal Pendidikan Profesi Guru, 1(1), 51-65. https://doi.org/10.22219/jppg.v1i1.12462.

Wijaya, H. (2018). Pengembangan Ilmu Pendidikan Berbasis Pendidikan Karakter Untuk meningkatkan Kecerdasan Spiritual. Researchgate.Net, 0-16.

Wulansari, T., Putra, A., Rusliah, N., \& Habibi, M. (2019). Pengaruh Model Pembelajaran Berbasis Masalah Pada Materi Statistika Terhadap Kemampuan Penalaran Statistis Siswa. Jurnal Aksioma: Jurnal Matematika Dan Pendidikan Matematika, 10(1), 35-47.

Yulianti, D., Wiyanto, Rusilowati, A., Nugroho, S. E., \& Supardi, K. I. (2019). Problem based learning models based on science technology engineering and mathematics for developing student character. Journal of Physics: Conference Series, 1170(1), 1-5. https://doi.org/10.1088/1742$\underline{6596 / 1170 / 1 / 012032 .}$ 